\title{
Lean Manufacturing and Business Performance in Brazilian Firms
}

\author{
Roberto Giro Moori \\ Universidade Presbiteriana Mackenzie \\ roberto.moori@mackenzie.br
}

\section{Adriano Pescarmona \\ Universidade Presbiteriana Mackenzie apescarmona@msn.com}

\section{Herbert Kimura}

Universidade Presbiteriana Mackenzie herbert.kimura@gmail.com

\begin{abstract}
In this paper, we examine the relationship among lean manufacturing management, competitive skills, and business performance from the perspective of managers of companies doing business in Brazil. We conduct a survey of 68 Brazilian companies that use lean manufacturing and analyze data using structural equation modeling based on partial least squares method. Results show, considering competitive skills as mediating variable, a positive relationship between lean manufacturing and business performance. Results also suggest that managers lack awareness about the importance of the competitive skills to enhance business performance.
\end{abstract}

Keywords: lean manufacturing, competitive skills, business performance. 


\section{INTRODUCTION}

Regarding management of technology, Womack, Jones and Roos (1992) suggested that in some decades, Lean Manufacturing, a term developed from the successful Toyota Production System (Brown, Lamming, Bessant, \& Jones, 2006), would prevail as a standard to conduct productive activities not only in Eastern countries but also in Western countries.

Lean manufacturing has been used in all continents and in various sectors including industry and service segments. Nevertheless, in the view of Womack et al. (1992), lean manufacturing throughout the world may not have been as decisive as it was first speculated, but its discussion, as a management tool that makes processes simpler, eliminates waste, establishes rational and productive flows, can help firms to improve business performance.

One could argue that the issue of the widespread use of lean manufacturing is not pacified. The huge recalls by Japanese automaker Toyota in 2010 questioned the benefits of this management model. Schonberger (2009), creator of the term "World Class Manufacturing", by following up financial statements of manufacturing companies, found that Toyota, despite initiatives to reduce waste in the period from 1990 to 2005, in fact showed a reduction of $3.4 \%$ of inventory turnover per year, i.e., an increase over the years in its inventory levels in comparison to sales.

To justify the lack of improvement in operating performance, Schonberger (2009) blames administrators and engineers who, because they have multiple functions, do not give appropriate attention to basic activities. In this context, concerns about generating new business outweigh the search for excellence in the production process. According to Balakrishnan, Linsmeier and Venkatachalam (1996), these contextual factors seem to influence the variability of managerial performance based on lean manufacturing.

One way to avoid the performance variability that results from contextual factors involves developing production strategies that add value to the customer. More specifically, through competitive skills, also denoted by Boyer and Lewis (2002) as competitive priorities, established jointly with customers, companies can support initiatives that enable lean manufacturing.
Based on these arguments, this study aims to investigate the following question that underlies this study: lean manufacturing system has direct and positive relationship with business performance? More specifically, the aim of this study is to evaluate, according to the opinion of managers of Brazilian companies, the mediate role of competitive skills in the relationship between management based on lean manufacturing and business performance.

The search for answers to the research problem contributes to the advancement of knowledge about lean manufacturing, through the presentation of evidence that could enable a better understanding of possible impacts of management decisions on business performance. The analysis of Brazilian firms is also a contribution, since it evaluates results of lean manufacturing in an environment that is not often studied in the scientific literature on business management. Additionally, according to Kaynak (2003), the available literature does not provide a definitive answer about how and what elements of lean manufacturing influence business performance and operational practices.

It is important to highlight that the use of intermediate variables to understand the relationship of the constituent elements of a production system is already widespread in studies of supply chain management (Green Jr, Whitten, \& Inman, 2008). Additionally, Fullerton, McWatters and Fawson (2003) and Fullerton and Wempe (2009) developed works that explore the use of intermediate variables in the analysis of the effect of operational management practices on business performance.

This study is structured as follows: the first part presents a literature review, focusing on the concepts of lean manufacturing management, competitive skills and business performance, fundamental constructs that support the hypotheses. The second part presents the methodology and the third, discusses the data analysis and results of the study. The fourth section presents the main conclusions, limitations of the study and suggestions for future research.

\section{THEORETICAL BACKGROUND AND HYPOTHESES}

Lean manufacturing is based on the rationale of removing activities that do not add value to the productive system, especially those associated with elapsed times, methods, processes, places, 
people and movements (Womack et al., 1992). The elimination of activities that do not add value allows a densification of work and a better match of activities that generate wealth. Accordingly, the increase in profit comes from the reduction of costs, which improves business performance of the company (Shingo, 1996).

However, to achieve the goal of improving performance, it is necessary to develop competitive skills (Dyer \& Singh, 1998; Skinner, 1969; Teece, Pisano \& Shuen, 1997; Wernerfelt, 1984) or operational capabilities associated with quality, flexibility and costs (Ferdows \& Meyer, 1990; Flynn \& Flynn, 2004).

Considering works such as Womack et al. (1992) and Ferdows and Meyer (1990), one can construct a conceptual model based on assumptions relating to management of lean manufacturing, competitive skills and business performance as shown in Figure 1. The main theoretical foundations that give support to the constructs and to the set of hypotheses of the study are presented below.

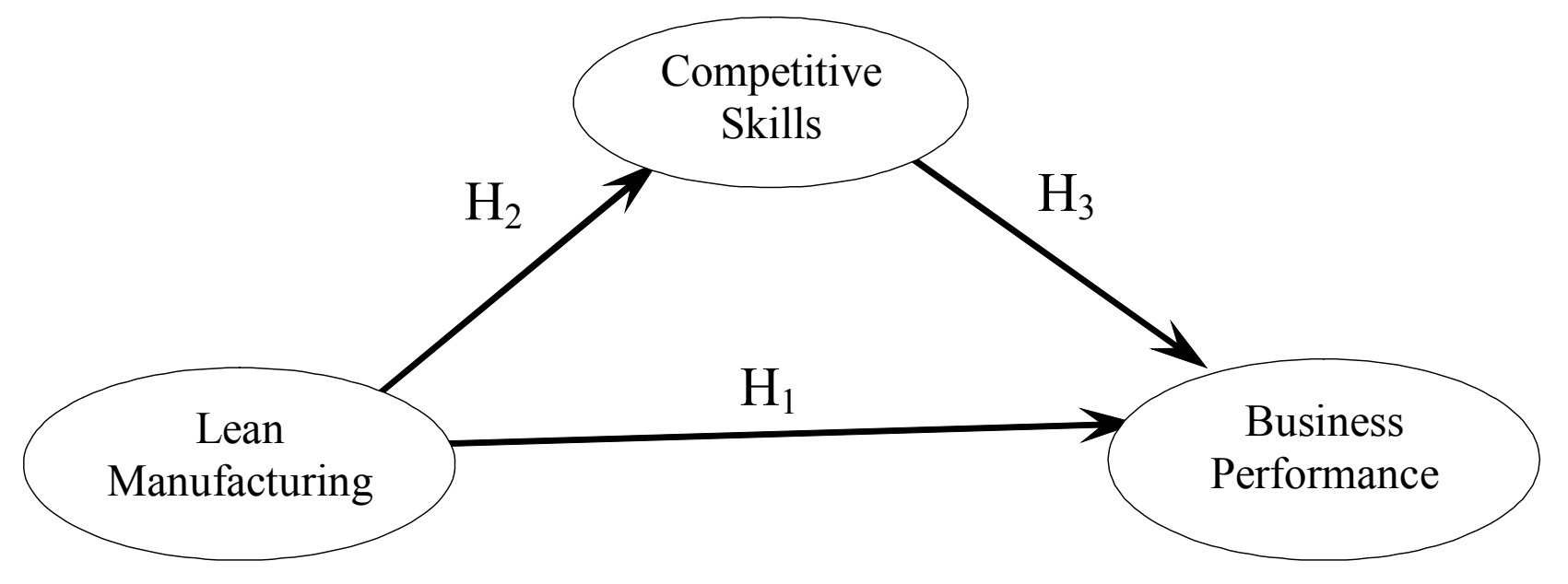

Figure 1: Model of the relationship among constructs: Lean Manufacturing Management and Business Performance mediated by Competitive Skills Source: the authors

\subsection{Lean Manufacturing Management and Business Performance}

Customers demand quality products, implying the need for various actions undertaken by the company involving production as, for example, deliveries in small lots within short deadlines (Christopher, 1999). To meet these demands, manufacturers have adopted initiatives aimed at reducing the setup time of equipment, making manufacturing cell manufacturing more flexible and improving quality. The production of small lots, for instance, requires frequent adjustments in the equipment and thereby reducing the setup time allows improvement of competitiveness by diminishing costs.

Moreover, companies with mass production generally have over-aged equipment in terms of market competitiveness (Fullerton \& Wempe, 2009). Consequently, many companies seek the flexibility and efficiency resulting from cell manufacturing. In this context, lean manufacturing mechanisms provide reduced costs of quality failures. It should be noted, however, that lean methods involve not only benefits but also costs. The effect of these methods on business performance is an open question, given the differences of empirical studies.

Results of previous studies vary. Some works have identified that the adoption of just-in-time tools or the use of models based on total quality management do not improve profitability (Hudson \& Nanda, 1995; Ittner \& Larcker, 1995). In contrast, other studies suggest a positive association between modern manufacturing practices and financial performance (Kinney \& Wempe, 2002; Fullerton et al., 2003). Considering the divergence of empirical findings, this paper seeks to examine the direct effects of lean production practices on performance, establishing the following hypothesis: 
H1: $\quad$ Efficient lean manufacturing management is positively associated with business performance

\subsection{Lean Manufacturing Management and Competitive Skills}

The design of a lean manufacturing system depends on attributes that may influence the behavior of the buyer. According to Chase, Jacobs and Aquilano (2006), different clients are attracted by different attributes. For example, some customers are more sensitive to the price of a product or service and therefore, in this case, companies should emphasize cost reduction.

Skills applied to competitive business strategies can be presented in different perspectives or dimensions as, for instance, those based on resources (Wernerfelt, 1984), on dynamic capabilities (Teece et al., 1997), on business relationships (Dyer \& Singh, 1998), on essential characteristics (Hamel \& Prahalad, 1995) or on competitive priorities (Skinner, 1969; Ferdows \& Meyer, 1990).

Competitive skills that can be considered closer to lean manufacturing management are the ones identified by Ferdows and Meyer (1990): quality, reliability, flexibility and cost. The study of Ferdows and Meyer (1990) does not deny the existence of trade-offs between generic industrial capabilities. Instead, the study suggests that the nature of these relationships depends on the compensation approach. Thus, if the approach focuses on cost, then cost and quality dimensions can be antagonistic, implying the existence of a trade-off, however if the approach is focused on quality, these dimensions can be simultaneously improved.

Accordingly, Swink, Narasimhan and Wang (2007) analyzed the integration of strategic objectives and the process of knowledge that manufacturing companies explore from interactions through external interfaces. Swink et al. (2007) note that, although performance variables such as marketing and customer satisfaction were correlated with financial measures, including market share, ROI (Return on Investment) and ROA (Return On Assets), results were not conclusive enough.

It must become clear that the implementation of a lean manufacturing system that allows obtaining a desired performance is difficult (Brown et al., 2006). Investment in training is necessary, since lean manufacturing implies greater capacity and flexibility, demanding individuals to perform functions on other productive units in case of need. Thus, Brown et al. (2006) suggest that qualified personnel, able to identify and resolve problems, may have greater autonomy and responsibility to make operational decisions, to get involved and to take active participation in issues facing quality, maintenance, and production schedule.

The quest for maximizing the flexibility associated with autonomy in decision making may involve defining new work arrangements, especially those grounded in teamwork. To examine the direct effects of the practices of lean manufacturing on competitive skills, we establish the following hypothesis:

H2: The efficient management of lean manufacturing is positively associated with competitive skills.

\subsection{Competitive Skills and Business Performance}

Lean manufacturing management mechanism linked to the principle of the Toyota Production System, in which increasing profits come from reducing costs, contrasts with the focus on margin, in which costs are unquestionable and added up to a desired profit level. The Toyota System favors larger gains emphasizing activities and processes that reduce costs, given a price set by consumers. From this perspective, the profit is the difference between price and cost (Shingo, 1996). This approach was innovative, since it confronted be common sense associated with price as the sum of costs and margin, which implied the transfer, to the consumer, of the additional costs of inefficiencies in the production processes.

Whereas the sustained profit should be a relevant goal of any company, there is a growing concern that, if profit is an end, the means by which it is obtained should be further explored. This perspective is similar to the Toyota Production System approach that emphasizes the role not only of profits but also of costs. From a practical standpoint, in many organizations, board meetings begin with a review and analysis of the financial position, showing that the financial result is a relevant element.

The functional relationships, the use of plant capacity and the production efficiency may be 
variables which generate results and therefore represent metrics by which business is evaluated and consequently controlled. The rationale behind this view is that performance is related to profitability and, therefore, management's attention to issues such as customer satisfaction, empowerment and commitment of employees (Christopher, 1999), i.e., competitive skills, may influence performance. To examine the direct effects of competitive skills on performance, we define the following hypothesis:

H3: Competitive skills is positively associated with business performance.

It is important to highlight that even though there are extensive studies of lean manufacturing not only in the international context (i.e., Shah \& Ward, 2003, 2007; Furlan, Vinelli, \& Pont, 2011; Eroglu \& Hofer, 2011) but also in the Brazilian environment (i.e., Arkader, 1999; Miyake, Torres Jr, \& Favaro, 2010; Corrêa \& Corrêa, 2011), none analyzes relationships mediated by competitive skills.

\section{METHODOLOGY}

To operationalize the model of a collaborative relationship shown in Figure 1, weinitially conducted an exploratory study. We sought, therefore, to understand the structure of the relationship model between lean manufacturing management and competitive skills and their impact on business performance in companies that admittedly adopted lean manufacturing management.

We developed a roadmap or guided interview based on scales and measures suggested by Womack and Jones (1998), Lewis (2000) and Fullerton and Wempe (2009). We submitted this roadmap, in a pilot study, to three experts with knowledge in the implementation of management systems based on lean manufacturing. The experts have strong academic background as well as broad experience in supply chain projects. Results of this preliminary study served as basis for the first version of a questionnaire. This version was submitted to a pre-test with five respondents with experience and knowledge in management and, more particularly, in lean manufacturing, to detect problems in the understanding or adequacy of the questions. The final version of the questionnaire, derived from criticism and observations from the respondents, was composed of six blocks.
The first and fifth blocks were related to the demographics of the respondents and characteristics of their firms. The second, third and fourth blocks referred, respectively, to the constructs: Lean Manufacturing with 23 indicators, Competitive Skills with 20 indicators and Business Performance with 9 indicators. In these blocks, the respondents were asked to choose their degree of agreement on a Likert scale ranging from Totally Disagree (TD $=1)$ to Totally Agree $(\mathrm{TA}=6)$. Finally, the sixth block referred to an open question that respondent could fill up and include additional information not covered by the structured questions.

It is important to establish that the questionnaire raises the perception or opinion of the respondent at any given time about management characteristics and about company's results. Evidently, the questionnaire responses may differ from the true values of the constructs analyzed bringing challenges to the empirical analysis.

Despite this limitation, it is argued that the questionnaire may also provide important insights into the perceptions of managers. Moreover, other metrics, primarily associated with financial performance, as profit, could be difficult to obtain, due to the level of disclosure of information that the company would be willing to accept. Because there are several privately held companies in the sample, financial performance information would be difficult to access and therefore we chose to collect opinion or estimates of managers on some performance metrics of their companies.

After defining and pre-testing the final version of the questionnaire, we selected a sample of firms drawn from the Brazilian Lean Institute, which comprises companies that practice lean manufacturing in the country. Before forwarding the questionnaires to prospective respondents, we sent an email explaining the research, including the option to complete the survey in an attached file or by accessing a website with an online form. Additionally, to expand the scope of our sample, we also sent invitations to members of LinkedIn communities related to lean manufacturing and asked them to answer the survey available online.

We applied descriptive statistics to analyze the demographic profile of respondents and firms and conducted an exploratory factor analysis to rule out variables that were not appropriately related to 
Moori, R. G., Pescarmona, A., Kimura, H.: Lean Manufacturing and Business Performance in Brazilian Firms

constructs. Afterwards, we ran a confirmatory factor analysis to verify the adequacy of measurements to the construct and used Cronbach's alpha to verify internal consistency of the construct as suggested by Hair, Anderson, Tatham and Black (2005). Finally, we applied structural equation modeling to assess the statistical significance of the relationship among latent variables composed of Lean Manufacturing Management, Competitive Skills and Business Performance.

Regarding the structural equation modeling estimation, we use PM-PLS (Partial Least SquaresPath Modeling). The PLS-PM has the following characteristics: the estimation is based on partial least squares; it allows the use of small samples (Smith \& Langfield-Smith, 2004); it admits the absence of some probability distribution properties such as normal distribution and allows the use of interval scales (Jöreskog \& Wold, 1982); it is able to include reflective and formative indicators simultaneously. In PM-PLS, the relative strengths among variables can be inferred by the factor loadings and the model adequacy can be obtained by Godness-of-Fit measures and by a mean coefficient of determination R2 as suggested by Tenenhaus, Vinzi, Chatelin and Lauro (2005) and Hair et al. (2005).

The study presents three basic limitations, due to the multivariate statistical techniques used on the research. The first is related to the very application of structural equation modeling. The technique is based on correlations that give an idea of how consistently two variables move together, however, do not explain why the dependence exists. The second limitation, as a result of the first, refers to the difficulty of the technique to eliminate external factors that could have caused the observed correlations. The third limitation is related to the data collection procedure and to sample size. The process of data gathering did not guarantee a random sample. Therefore, inferences about the results should be viewed with caution, since they cannot be generalized to the population of Brazilian firms that practice lean manufacturing. In addition, sample size may impose restrictions on the convergence or consistency of results.

\section{DATA ANALYSIS AND RESULTS OF THE STUDY}

During the period between January and March of 2011, we obtained a sample of 69 questionnaires or respondents. One questionnaire was discarded, leaving 68 questionnaires suitable for data analysis.

\subsection{Demographic Profile}

The sample of companies practicing lean manufacturing management consisted of $57 \%$ from the metal-mechanic sector, $14 \%$ from the automakers and auto parts sector, $15 \%$ from the chemical and pharmaceutical sector, $8 \%$ from paper and packaging sector and $6 \%$ from the service sector. Most (78\%) of the surveyed firms are from the state of São Paulo, spread over areas of the Paraíba Valley (32\%), São Paulo metropolitan area (30\%), Campinas metropolitan area $(20 \%), \mathrm{ABCD}$ area $(10 \%)$ and Sorocaba area (6\%). Most companies had revenues greater than $\$ 60$ million in 2010, employing with more than 500 people each. Only five firms were smaller, employing between 10 and 99 employees.

All companies in the sample had structured and specialized programs dedicated to the deployment and management of lean manufacturing. Many of the companies in the sample sought to be at the forefront of knowledge and implementation of lean manufacturing techniques in Brazil, with strong presence in professional forums and discussions on the subject. In summary, sample data was gathered from a qualitatively and representative group of Brazilian firms that emphasizes lean manufacturing management. Companies in this study can also be considered references in their field of business, and some stand out for their performance and excellence in management.

Regarding the experience of respondents with lean manufacturing, $63.5 \%$ had more than five years of experience, $10.6 \%$ had between three and five years of experience. Regarding the functions of the respondents, $86 \%$ had managerial positions, $11 \%$ were directors and $3 \%$ were CEOs of the companies.

\subsection{VALIDATION OF MEASURES AND SCALES}

We first conducted factor analysis to validate measures and scales. According to Hair et al. (2005), for a sample greater than 100 respondents, factor loadings greater than 0.50 are considered to have practical significance. Although the sample consists of only 68 respondents, we removed variables with factor loadings lesser than 0.5 and recalculated the internal reliability, the composite reliability and average variance extracted. After revaluation, from 
the total of 52 indicators, we obtained a revised model comprised of 19 items distributed in three constructs: Lean Manufacturing Management, Competitive Skills and Business Performance, consisting of eight, four and seven indicators, respectively.

The results of the factor analysis may suggest that the observable variables do not adequately represent latent constructs. We decided not to follow only one scale from a given reference, but instead chose to integrate concepts from Womack and Jones (1998), Lewis (2000) and Fullerton and Wempe (2009). This exploratory procedure may have resulted in a scale that could lead to the discard of some variables in the factor analysis due to low correlation, since the references bring together not only lean manufacturing variables, but also variables related to competitive advantage and financial and nonfinancial performance.

It is important to highlight that since the traditional correlation is a measure of linear relationship, factor analysis would also discard variables that have strong but non-linear relationships. Another argument for poor results of the factor analysis may be related to the potential influence of respondents' opinion. Personal perception of respondents about variables may result in low correlation between measured and latent variables that contrasts theoretical expectations.

But the main argument for the results of factor analysis is that the very latent variables are themselves multidimensional. For instance, of the overall 23 measures of lean manufacturing, 5 were related to empowerment of employees to solve problems, 7 to a pull system of production, 5 to waste reduction and 6 to focus on client. Therefore, all 23 variables should be related to different subdimensions of lean manufacturing. Similarly, for the latent variable related to competitive skills, there were 5 measured variables for each of the 4 subdimensions: quality, reliability, process flexibility and cost.

Thus, ideally, we should have implemented a structural model with different levels of latent variables. For instance, competitive skills should be a latent variable associated with other four latent variables. Unfortunately, the use of more levels of latent variables was unattainable, due to the small sample size.

Descriptive statistics of the 19 indicators that resulted from the factor analysis, such as mean, standard deviation, individual factor loadings, squared loading, residual variance, $\alpha$ (Cronbach's alpha), AVE (Average Variance Expected) and CR (Composite Reliability), are shown in Table 1.

Table 1: Results of reliability and validation

\begin{tabular}{l|c|c|c|c|c|c}
\hline CONSTRUCTS / STATEMENT & Mean & S.D. & Loading & $\begin{array}{c}\text { Squared } \\
\text { loading }\end{array}$ & $\begin{array}{c}\text { Residual } \\
\text { variance }\end{array}$ \\
\hline \multicolumn{2}{c|}{ Lean Manufacturing Management } \\
\hline $\begin{array}{l}\text { E1 Operators are part of problem-solving teams } \\
\text { E2 }\end{array}$ & 4.72 & 1.16 & 0.833 & 0.694 & 0.306 \\
\hline $\begin{array}{l}\text { Eroduction is pulled through shipment/sales } \\
\text { of finished products }\end{array}$ & 3.76 & 1.59 & 0.736 & 0.541 & 0.459 \\
\hline $\begin{array}{l}\text { E3 Products advance the workstations through } \\
\text { the demand of subsequent stations }\end{array}$ & 3.87 & 1.46 & 0.784 & 0.614 & 0.386 \\
\hline $\begin{array}{l}\text { E4 Production rate is directly related to } \\
\text { customer demand }\end{array}$ & 4.37 & 1.45 & 0.819 & 0.671 & 0.329 \\
\hline $\begin{array}{l}\text { E5 Equipment/workstations considered } \\
\text { bottlenecks are monitored }\end{array}$ & 4.53 & 1.25 & 0.831 & 0.690 & 0.310 \\
\hline $\begin{array}{l}\text { E6 There are frequent activities to identify and } \\
\text { eliminate waste in the operation }\end{array}$ & 4.56 & 1.01 & 0.810 & 0.656 & 0.344 \\
\hline $\begin{array}{l}\text { E7 Processes considered bottlenecks are } \\
\text { identified and monitored in production }\end{array}$ & 4.75 & 1.25 & 0.784 & 0.615 & 0.385 \\
\hline $\begin{array}{l}\text { E8 The concept of adding value is disseminated } \\
\text { in the operation }\end{array}$ & 4.21 & 1.14 & 0.702 & 0.493 & 0.507 \\
\hline
\end{tabular}


COMPETITIVE SKILLS $\alpha=0.777 ;$ AVE $=0.600 ; C R=0.857$

\begin{tabular}{l|c|c|c|c|c}
\hline C1 General perception of quality by customers & 4.84 & 1.17 & 0.738 & 0.544 & 0.456 \\
\hline $\begin{array}{l}\text { C2 Flexibility in delivery (capacity to meet the } \\
\text { increased complexity of deliveries with the } \\
\text { same characteristic of assets) }\end{array}$ & 4.82 & 1.09 & 0.806 & 0.650 & 0.350 \\
\hline $\begin{array}{l}\text { C3 Ability to convert a product to attend } \\
\text { customer demand (urgent request) }\end{array}$ & 4.84 & 1.18 & 0.821 & 0.674 & 0.326 \\
\hline $\begin{array}{l}\text { C4 Positive effects on the cost associated } \\
\text { with labor }\end{array}$ & 4.82 & 0.88 & 0.730 & 0.532 & 0.468 \\
\hline
\end{tabular}

BUSINESS PERFORMANCE $\alpha=0.903 ;$ AVE $=0.637 ; C R=0.924$

\begin{tabular}{l|c|c|c|c|c}
\hline D1 Return on assets before taxes (ROA) & 4.31 & 1.18 & 0.904 & 0.818 & 0.182 \\
\hline D2 Return on investments (ROI) & 4.37 & 1.11 & 0.899 & 0.809 & 0.191 \\
\hline $\begin{array}{l}\text { D3 Earnings before taxes. depreciation and } \\
\text { amortization (EBITDA) }\end{array}$ & 4.44 & 1.14 & 0.746 & 0.557 & 0.443 \\
\hline D4 Operational margin & 4.62 & 1.05 & 0.800 & 0.640 & 0.360 \\
\hline D5 Strategic positioning & 4.87 & 1.01 & 0.706 & 0.498 & 0.502 \\
\hline D6 Percentage of sales from new products & 4.04 & 1.33 & 0.742 & 0.550 & 0.450 \\
\hline D7 Increased sales in strategic segments & 4.24 & 1.40 & 0.768 & 0.589 & 0.411 \\
\hline
\end{tabular}

Obs: statements of questionnaire follows a Likert scale from 1 to 6 (Totally Disagree to Totally Agree) Source: Data from study

All indicators showed factor loadings above 0.7 and squared loadings over $50 \%$, as suggested by Hair et al. (2005). The analysis of the constructs, reliability and convergent and discriminant validation are described below:

a) Considering the descriptive assessment of constructs, we found that respondents demonstrated that lean manufacturing management and competitive skills favored business performance, since the answers were on the concordant side of the scale. However, statements E2 and E3 suggest that demand as trigger of the production is still incipient, i.e., the output is pulled rather than pushed by the market.

b) Regarding the internal reliability of the items, Cronbach's alpha was above 0.7 suggesting that the indicators that formed the constructs can be considered acceptable.

c) The study of convergent validity, assessed by the average variance extracted and composite reliability, suggests that all constructs have values above the recommended values of 0.6 and 0.8 , respectively (Hair et al., 2005). The composite reliability and the Cronbach's alpha allow assessing whether an indicator adequately measures the construct (Hair et al., 2005).

d) In assessing the discriminant validity, through the cross-loadings, we observed, in all cases, that the square root of the average variance extracted was higher than the correlation among the constructs, suggesting that the indicators are more intensely related to their respective constructs than any other construct considered in the model (Tenenhaus et al., 2005).

Table 2 shows the values of the correlation between the constructs, and in its diagonal, the square root of the average variance extracted. Once verified the validity of indicators and constructs, we proceed to the analysis of the structural equations model.

Table 2: Correlation between constructs and square root of average variance extracted (diagonal)

\begin{tabular}{l|c|c|c}
\hline \multicolumn{1}{c|}{ CONSTRUCTS } & 1 & 2 & 3 \\
\hline 1. Lean Manufacturing Management & $\mathbf{0 . 7 8 9}$ & & \\
\hline 2. Competitive Skills & 0.361 & $\mathbf{0 . 7 7 5}$ & \\
\hline 3. Business Performance & 0.615 & 0.586 & $\mathbf{0 . 7 9 8}$ \\
\hline
\end{tabular}

Source: Data from study 


\subsection{Evaluation of the Relationships in the Structural Measurement Model}

We present results from the analysis of structural relationships in models with and without the mediation effect of the construct Competitive Skills. Considering the mediation effect of Competitive Skills, the analysis of the structural equations model is shown in Figure 2.

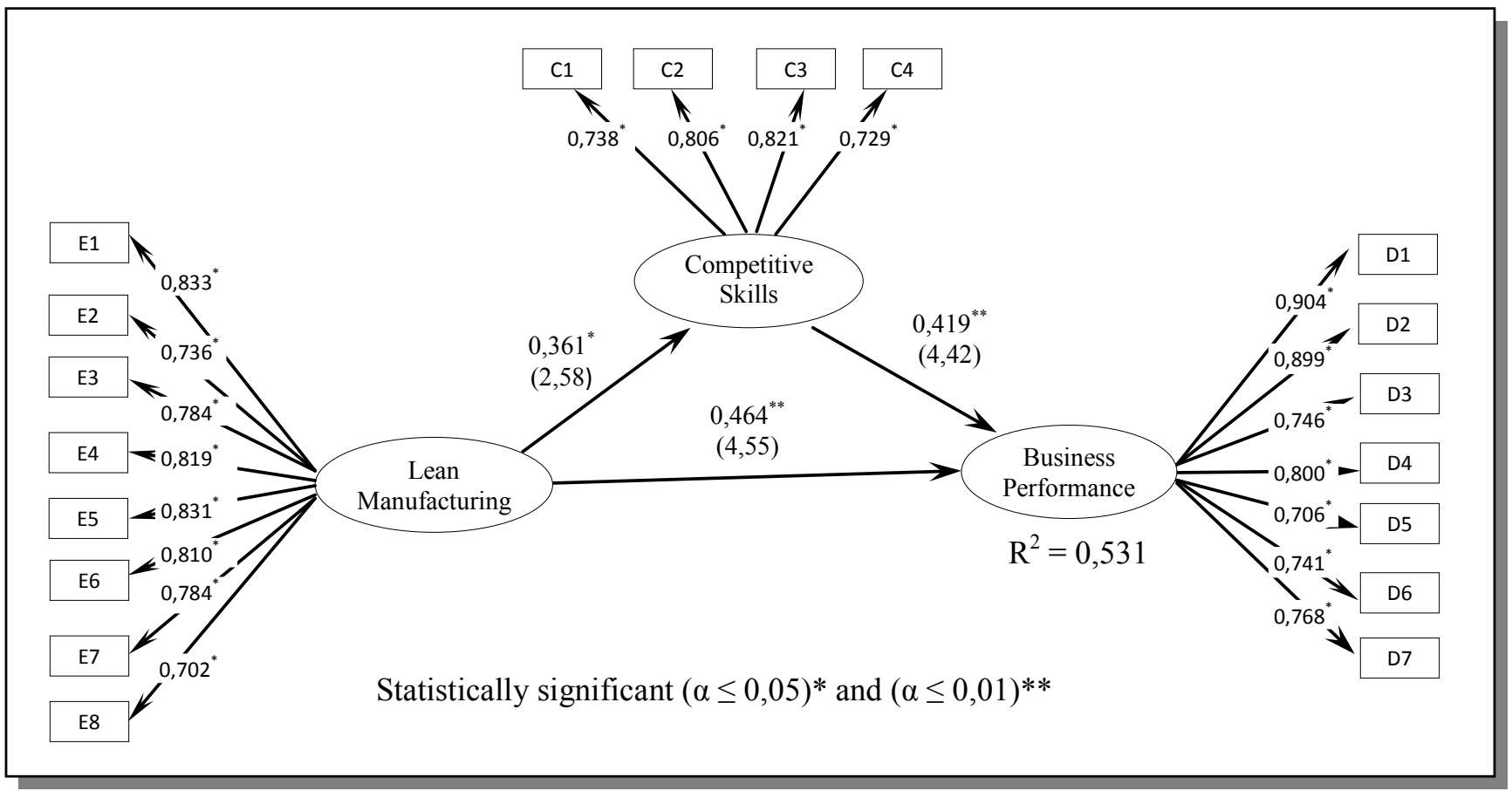

Figure 2: Revised model

Obs: Procedure based on SmartPLS software version 2.0 M3 (RINGLE et al., 2005) and significance level estimated using bootstrap with $\mathrm{n}=$ and 2000 resamples.

Source: Data from study

With respect to the fitness of the model, the coefficient of determination (R2) for Competitive Skills and Business Performance were $13.0 \%$ and $53.1 \%$, respectively. Cohen (1977) considers $26 \%$ as a large effect for the behavioral sciences field. As for the Godness of Fit (GoF), which commonality is equal to the average variance extracted in PLSPM model, Fornell and Larcker (1981) proposed a minimum value equal to 0.5 . Substituting the values of R2 suggested by Cohen (1977) and the commonality established by Fornell and Larcker (1981), one can get the minimum adjustment value of GoF equal to 0.36 (Wetzels, Odekerken-Schröder, \& Van Oppen, 2009). In this study, the GoF is equal to 0.45 , suggesting that the model showed a good fit compared to the specified minimum.

The statistical significance of structural relations of the model and hypothesis testing are shown in Table 3.

Tabela 3:

\begin{tabular}{l|c|c|c|c|l}
\hline \multicolumn{1}{c|}{$\begin{array}{c}\text { Structural } \\
\text { relationship }\end{array}$} & $\begin{array}{c}\text { Structural } \\
\text { coefficients }\end{array}$ & $\begin{array}{c}\text { Standard } \\
\text { error }\end{array}$ & T value & Hypothesis & Decision \\
\hline $\begin{array}{l}\text { Lean Manufacturing Management } \rightarrow \text { Business } \\
\text { Performance }\end{array}$ & 0.464 & 0.102 & 4.55 & $\mathrm{H}_{1}{ }^{* *}$ & Supported \\
\hline $\begin{array}{l}\text { Lean Manufacturing Management } \rightarrow \text { Competitive } \\
\text { Skills }\end{array}$ & 0.361 & 0.140 & 2.58 & $\mathrm{H}_{2}{ }^{*}$ & Supported \\
\hline Competitive Skills $\rightarrow$ Business Performance & 0.419 & 0.095 & 4.42 & $\mathrm{H}_{3}{ }^{* *}$ & Supported \\
\hline
\end{tabular}

$\left({ }^{* *}\right)<0.01$ : level of significance $(t>2.58) ;\left({ }^{*}\right)<0.05$ : level of significance $(t>1.96)$ Source: Data from study 
Hypotheses $\mathrm{H} 1$ and $\mathrm{H} 3$ were validated at a 0.01 significance level and Hypothesis $\mathrm{H} 2$ was validated at a 0.05 significance level, suggesting a relevant contribution of Lean Manufacturing and Competitive Skills on Business Performance, as perceived by the respondents.
Considering the relationship between Lean Manufacturing and Business Performance without the mediation of Competitive Skills, results are shown in Figure 3.

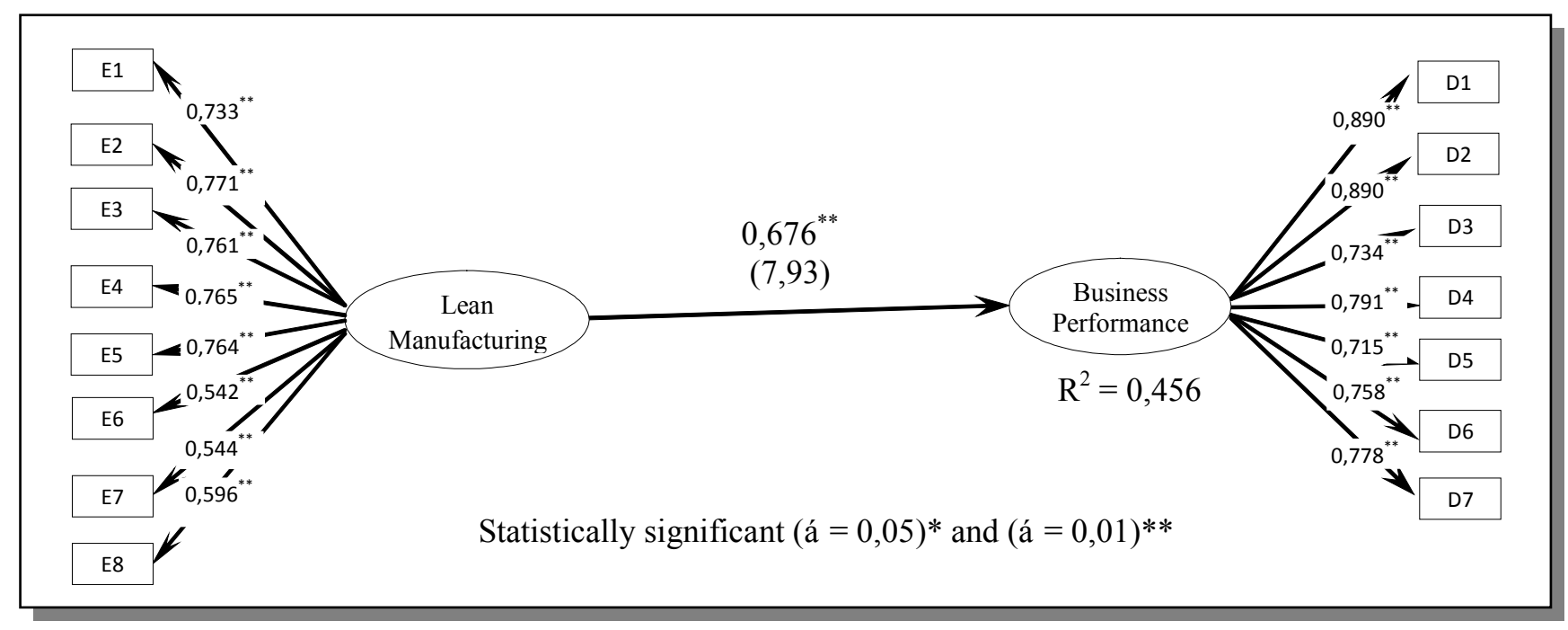

Figure 3: Revised model without mediating variable

Obs: Procedure based on SmartPLS software version 2.0 M3 (Ringle et al., 2005) and significance level estimated using bootstrap with $n=68$ and 2000 resamples.

Source: Data from study

From Figure 3, we observe that while the model without the mediation effect of Competitive Skills has an R2 equal to 0.456 and a GoF equal to 0.504 , the model including the mediating variable has an $\mathrm{R} 2$ equal to 0.531 and a GoF equal to 0.45 . In the model without mediation, the correlation coefficient between Lean Manufacturing Management and Business Performance was equal to 0.676 with $t$ value of 7.93. These values were far superior from those shown in the structural model with the mediating variable depicted in Figure 2 (0.464 for the correlation coefficient and 4.55 for the $t$ value).

Therefore, considering de procedure for checking the effect of a mediating variable as suggested by Baron and Kenny (1986) and Vieira (2009), the stronger correlation presented by the structural model without the variable Competitive Skills highlights the mediating effect of this variable in explaining the relationship between Lean Manufacturing Management and Business Performance.

\section{FINAL COMMENTS}

The study presents evidence that is consistent with the formulated hypotheses. Data analysis confirmed the dependence between the construct Business Performance and the constructs Competitive Skills and Lean Manufacturing Management. Although the research hypotheses were confirmed, it became evident that the direct relationship between Business Performance and Lean Manufacturing Management was more significant than the mediated relationship with Competitive Skills. From the literature review, one can identify the difficulty of measuring the effects of management on business results, since there is no clarity on how, and to what extent, lean manufacturing practices affect operating and financial performance of a firm.

We identified a low statistical significance on the direct relationship between Lean Manufacturing Management and Competitive Skills, highlighting the role of managers in generating Business Performance. This result can be related to the work of Swink et al. (2007) that analyzes the actions of managers and their potential impacts on operating activities and on business performance.

The analysis of the model that omits the construct 
Competitive Skills also demonstrated the effects of management, as an intermediate role of employment of lean manufacturing management practices, on Business Performance. There was a direct relationship between the elements of Lean Manufacturing Management and Business Performance. In this respect, the influence of the Lean Manufacturing Management in Operating Performance was more significant without the mediate effect of Competitive Skills.

Considering a sample of Brazilian firms, evidence suggests that managers showed little awareness of the impact of their activities on Competitive Skills, focusing more on Business Performance. This result may reflect a departure of operational management from guidelines for business management. This detachment can be justified by the focus on shortterm results and little visibility of how management actions related to productive operations can positively affect business performance. The companies established in Brazil perhaps only more recently have begun to worry about the durability and sustainability of business performance, suffering from lack and deficiency in training operations managers.

In this sense, there is still need for development of training programs for entrepreneurs, executives and business owners as well as for operations managers, geared more toward value creation and business sustainability. Still, it is important to note that, in this study, we did not intend to generalize the findings to all cases of implementation of lean manufacturing, but we did intend to raise discussions that could stimulate further research on this topic.

Some limitations of the study should be highlighted. As for the scope, we relied on the experience of managers of national and multinational companies with operations in Brazil who worked with implementation of lean manufacturing in the last decade. The analysis was restricted to relationships among the company's internal deployment of lean manufacturing, the competitive skills and the business performance. Thus, we sought to understand how elements of lean manufacturing in the management of internal processes can affect business outcome, independently from exogenous factors, e.g., economic variables. Fleury and Arkader (1997) compared manufacturing strategies in Brazil and Argentina, considering economic environment.
Another important limitation is related to the small sample size. However, since the main objective of the paper is based on the study of relationships among latent variables, the lesser number of relevant variables from the factor analysis, combined with the path modeling based on Partial Least Squares may reduce the small sample limitation.

In particular, PLS-PM can be considered an adequate approach to the study of small samples (Hoyt, 1999; Smith \& Langfield-Smith, 2004). For small samples, structural equations models based on PLS are preferred to models based on LISREL, for instance. If we were to follow Hoyt (1999), the use of a regression heuristic of 10 cases per predictor would compromise results from regression analysis. Therefore, we did not conduct traditional regression analysis. In this case, an adequate number of observations would be 10 times the greater between "the block of the largest number of formative indicators (i.e., largest measurement equation) or the dependent latent variable with the largest number of independent latent variables influencing it (i.e., largest structural equation)" (Hoyt, 1999, p. 326).

Considered by some researchers as a silver bullet to address structural models (Marcoulides \& Saunders, 2006), PLS is extensively used with small samples. One argument is that the overall model is more relevant than sample size (Falk \& Miller, 1992). However, we should emphasize that the small sample debate is far from over. According to Goodhue, Lewis and Thompson (2012) "major MIS journals have published studies using PLS with sample sizes that would be deemed unacceptably small if used with other statistical techniques".

Marcoulides and Saunders (2006) present a table that, depending on some characteristics of the model, under normality assumptions, sample size can be as low as 15 observations with PLS, which is less than the 68 observation of our study. By using bootstrapping techniques, we build confidence intervals without the need of normality assumptions.

Although leading journals have published papers using PLS on a small sample, we are aware of limitations. For instance, "when used with small sample sizes, PLS, like the other techniques, suffers from increased standard deviations, decreased statistical power, and reduced accuracy" (Goodhue et al., 2012). 
As for the design, the research did not address aspects of the evolution of the deployment of elements of lean manufacturing, competitive skills and business performance, since no longitudinal analysis was conducted. We also did not contemplate control variables. For instance, Shah and Ward (2003) examined effects of contextual factors such as plant size, age and unionization status. There was no comparison between users and non-users of lean manufacturing. Suggestions for further studies include expanding the sample to ensure consistency of the exploratory data analysis and the consideration of variables over time or in situations before and after deployment of lean manufacturing management.

\section{REFERENCES}

Arkader, R. (1999). Avanços e barreiras ao fornecimento enxuto da indústria automobilística brasileira: a perspectiva dos fornecedores. Revista de Administração Contemporânea, 3(1), 7-21.

Balakrishnan, R., Linsmeier, T. J., \& Venkatachalam, M. (1996). Financial benefits from JIT adoption: effects of customer concentration and cost structure. The Accounting Review, 71(2), 183-205.

Baron, R. M.; Kenny, D. A. (1986). The ModeratorMediator Variable Distinction in Social

Psychological Research: Conceptual, Strategic, and Statistical Considerations. USA:

Journal of Penality and Social Psychology, 51(6), pp. 1173-1182.

Boyer, K. K., \& Lewis, M. W. (2002). Competitive priorities: investigating the need for trade- of $\mathrm{f} \mathrm{s}$ in operations strategy. Production and Operations Management, 11(1), 9-20.

Brown, S., Lamming, R., Bessant, J., \& Jones, P. (2006). Administração da Produção e Operações. Rio de Janeiro: Editora Campus/Elsevier.

Chase, R. B., Jacobs, F. R.,\& Aquilano, N. J. (2006). Administração da Produção para a Vantagem Competitiva. Porto Alegre: Bookman.

Christopher, M. (1999). O Marketing da Logística. Otimizando Processos para Aproximar Fornecedores e Clientes. São Paulo: Futura.

Cohen, J. (1977). Statistical power analysis for the behavioral sciences (revised edition). New York: Academic Press.

Corrêa, C. A., \& Corrêa, H. L. O Processo de Formação de Estratégias de Manufatura em Empresas Brasileiras de Médio e Pequeno Porte. Revista de Administração Contemporânea, 15(3), 454-475.

Dario, I. M., Torres Jr., A. S., \& Favaro, C. (2010). Supply Chain Mapping Initiatives in the Brazilian Automotive Industry: Challenges and Opportunities. Journal of Operations and Supply Chain Management, 3(1), pp 79 - 97

Dyer, J. H., \& Singh, H. (1998). The relational view: cooperative strategy and sources of interorganizational competitive advantage. Academy of Management Review, 23(4), 660-679.

Eroglu, C., \& Hofer, C. (2011). Lean, leaner, too lean? The inventory-performance link revisited Journal of Operations Management, 29(4), 356-369

Falk, R. F., \& Miller, N. B. (1992). A Primer of Soft Modeling. Akron: The University of Akron Press.

Ferdows, K., \& Meyer, A. (1990). Lasting Improvements in Manufacturing Performance: in Search of a New Theory. Int. Journal of Operations and Production Management. 9(2), 168-184.

Fleury, P. F. \& Arkader, R. (1997). Estratégia de Manufatura eAmbiente Econômico: Comparando Desempenhos e Trajetórias de Brasil e Argentina. Revista de Administração Contemporânea, 1(2), 7-23.

Flynn, B. B., \& Flynn, J. E. (2004). An Exploratory Study of the Nature of Cumulative Capabilities. Journal of Operations Management, 22, 439-457.

Fornell, C., \& Larker, D. (1981). Evaluating structural equation models with unobservable variables and measurement error. Journal of Marketing Research, 18(1), 39-50.

Fullerton, R. R., McWatters, C. S., \& Fawson, C. (2003). An examination of the relationships between JIT and financial performance. Int. Journal of Operations and Production Management, 21, 383-404.

Fullerton, R. R., \& Wempe, W. F. (2009). Lean manufaturing, non-financial 
performancemeasures, and financial performance. Int. Journal of Operations and Production Management, 29(3), 214-240.

Furlan, A., Vinelli, A., \& Pont, G. (2011). Complementarity and lean manufacturing bundles, Int. Journal of Operations and Production Management, 31(8), 835-850.

Goodhue, D. L., Lewis, W., \& Thompson, R. 2012. Does PLS have advantages for small sample size or non-normal data? MIS Quarterly, 36(3), 8911001.

Green Jr., K. W., Whitten, D., \& Inman, R. A. (2008). The impact of logistics performnce on organizational performance in a supply chain context. Supply Chain Management: An International Journal, 13(4), 317-327.

Hair J. F., Anderson, R. E., Tathan, R. L., \& Black, W. C. (2005). Análise de Dados Multivariados. Porto Alegre: Editora Bookman.

Hamel, G., \& Prahalad, C. K. (1995). Competindo pelo Futuro. Rio de Janeiro: Editora Campus.

Hoyt, R. (1999). Statistical Strategies for Small Sample Research. Sage Publications.

Hudson, M., \& Nanda, D. (1995). The Impact of Just-in-time Manufacturing on Firm Performance in the US. Journal of Operations Management, 12(3/4), 297-310.

Ittner, C. D., \& Larcker, D. F. (1995). Total Quality Management and the Choice of Information and Reward Systems. Journal of Accounting Research, 33(3), 1-34.

Jöreskog, K. G., \& Wold, H. (1982). The ML and PLS techniques for modeling with latent variables: historical and comparative aspects. In: Jöreskog, K. G.; Wold, H. (Ed.) Systems under indirect observation: causality, structure, prediction. Part I. Netherlands: North-Holland Publishing Company.

Kaynak, H. (2003);. The relationship between total quality management practices and their effects on firm performance. Int. Journal of Operations and Production Management, 21, 405-435.

Kinney, M. R., \& Wempe, W. F. (2002). Further evidence on the extent origins of JIT's profitability effects. The Accounting Review, 77(1), 203-25.

Lewis, M. A. (2000). Lean production and sustainable competitive advantage. Int. Journal of Operations and Production Management, 20(8), 959978.

Marcoulides, G. A., \& Saunders, C. (2006). PLS: a Silver Bullet? Editor's comments. MIS Quarterly, 30(2), iii-ix.Ringle, C. M., Wende, S., \& Will, A. (2010). SmartPLS 2.0 M3 (beta). Germany: University of Hamburg. Available at: <http:// www.smartpls.de>. Access in: 18/05/2010.

Schonberger, R. J. (2009). The Lean League. Available at: www.worksmanagement.co.uk Access in: 17/02/2013.

Skinner, W. (1969). Manufacturing - Missing Link in Corporate Strategy. USA: HBR.

Shah, R., \& Ward, P. T. (2003). Lean Manufacturing: Context, Practice Bundles, and Performance. Journal of Operations Management, 21(2), 129-149.

Shah, R., \& Ward, P. T. (2007). Defining and developing measures of lean production Journal of Operations Management, 25(4), 785-805

Shingo, S. (1996). O sistema Toyota de Produção: do ponto de vista da Engenharia da Produção. Porto Alegre: Editora Bookman.

Smith, D., \& Langfield-Smith, K. (2004). Structural equation modeling in management accounting research: critical analysis and opportunities. Journal of Accounting Literature, 23, 49-86.

Swink, M., Narasimhan, R., \& Wang, C. (2007). Managing beyond the factory walls: effects of four types of strategic integration on manufacturing plant performance. Journal of Operations Management, 25(1): 148-164.

Teece, D. J., Pisano, G., \& Shuen, A. (1997). Dynamic Capabilities and Strategic Management. Strategic Management Journal, 18(7), 509-533.

Tenenhaus, M., Vinzi, V. E., Chatelin, Y., \& Lauro, C. (2005). PLS - Path Modeling. Computational Statistics \& Data Analysis, 48, 159-205.

Vieira, V. A. (2009). Moderação-mediação, Moderadora-mediadora e Efeitos Indiretos 
em Modelagem de Equações Estruturais: Uma Aplicação no Modelo de Desconfirmação de Expectativas. Revista de Administração, 44(1), 1733.

Wernerfelt, B. (1984). A resource-based view of the firm. Strategic Management Journal, 5(2), 171-180.

Wetzels, M., Odekerken-Schröder, G., \& Van Oppen, C. (2009). Using PLS Path Modeling For Assessing Hierarchical Construct Models: Guidelines and Empirical Illustration. USA: MIS Quarterly, 33(1), 177-195.

Womack, J. P., Jones, D. T., \& Roos, D. (1992). A máquina que mudou o mundo. Rio de Janeiro: Campus.

Womack, J. P., \& Jones, D. T. (1998). A mentalidade enxuta nas empresas. 4ed. Rio de Janeiro: Campus. 


\section{AUTHOR'S BIOGRAPHY}

Roberto Giro Moori: Doctor and Master Degree in Production Engineering (University of Sao Paulo), Bachelor Degree in Mechanical Engineering (Paulista State University) Professor of Logistics and Supply Chain Strategy Affiliated Research Centre: Postgraduate Program in Business Management, Mackenzie Presbyterian University, Sao Paulo, Brazil. Research Group: Logistic and Supply Chain Management

Adriano Pescarmona: Master Degree in Business Management (Mackenzie Presbyterian University), Bachelor Degree in Metallurgical Engineering (USP - Sao Paulo University).

Supply Chain Manager. Affiliated Company: Dow Agrosciences Ind. Ltda. Research Group: Logistic and Supply Chain Management

Herbert Kimura: Doctor Degree in Business Administration and Master Degree in Statistics (University of Sao Paulo), Bachelor Degree in Electronics Engineering (Aeronautics Institute of Technology). Professor of Business Administration Affiliated Research Centre: Postgraduate Program in Business Management, Mackenzie Presbyterian University, Sao Paulo, Brazil Research Group: Logistic and Supply Chain Management 